\title{
Rapid Equilibration of Warfarin Between Rat Tissue and Plasma
}

\author{
Theodore J. Benya ${ }^{1}$ and John G. Wagner ${ }^{2,3}$
}

Received Oct. 21, 1974-Final Mar. 11, 1975

\begin{abstract}
Plasma and tissue concentrations of warfarin in the rat were measured as a function of time following a $10 \mathrm{mg} / \mathrm{kg}$ intravenous dose. The mathematical interpretation of the experimental results suggested that the data could be explained in terms of a two-compartment open model. Following equilibration, which occurred within a few mimutes after injection, individual tissue levels and plasma levels of warfarin were found to be always directly proportional.
\end{abstract}

KEY WORDS: warfarin; linear pharmacokinetics; tissue binding; plasma protein binding; tissue distribution.

\section{INTRODUCTION}

The purpose of this study was to derive a pharmacokinetic model which would describe the relationship between tissue and plasma concentrations of warfarin in rats, as a function of time, following an intravenous dose of sodium warfarin, $10 \mathrm{mg} / \mathrm{kg}$.

Forty male Sprague-Dawley rats with an average weight of $300 \mathrm{~g}$ were used in the study of eight time intervals: $1,5,15,30,60,120,180$, and $240 \mathrm{~min}$. Five animals were used for each time interval, four serving as recipients and the fifth as a blank.

Supported by Training Grant GM 1367-10 from the National Institute of General Medical Sciences, U.S. Public Health Service, Bethesda, Maryland 20014.

${ }^{1}$ Present address: College of Pharmacy, Ohio Northern University, Ada, Ohio 45810.

${ }^{2}$ College of Pharmacy and Upjohn Center for Clinical Pharmacology, University of Michigan, Ann Arbor, Michigan 48104.

${ }^{3}$ Address requests for reprints to Dr. J. G. Wagner, Upjohn Center for Clinical Pharmacology, University of Michigan, Ann Arbor, Michigan 48104. 


\section{EXPRRTMENTAL}

\section{Animal Treatment}

The rats were starved the night before the experiment and during the experiment; water only was allowed ad libitum. The rats were weighed in the morning prior to the experiment, and $3 \mathrm{mg}$ of sodium warfarin was administered intravenously by tail vein, based on their average weight. The rats were not anesthetized during the injection.

At the end of each time interval, the corresponding rats were anesthetized with ether U.S.P. An abdominal incision was made, and an immediate blood sample was taken from the bifurcation of the inferior vena cava. The needle was then detached and the sample transferred slowly to prevent hemolysis against the inside of a 17 - by $100-\mathrm{mm}$ plastic vial containing $0.2 \mathrm{ml}$ of sodium citrate, $25 \% \mathrm{w} / \mathrm{v}$. The plasma was separated by centrifugation and transferred by pipette into new plastic vials, capped, and frozen at $-4^{\circ} \mathrm{C}$. The rats were then decapitated, and the following were organs excised, transferred to plastic vials, capped, and frozen at $-4^{\circ} \mathrm{C}$ : brain, heart, lung, spleen, and liver.

Tissue homogenates were prepared and then refrozen until assayed. Each homogenate run represented the same organ for a given time interval. For example, all five hearts excised at $1 \mathrm{~min}$ after injection were first thawed, blotted, and weighed, and then exactly $0.7 \mathrm{~g}$ of tissue from each heart was weighed into a separate, tared $15-\mathrm{ml}$ Broeck glass tissue grinder and homogenized with $7 \mathrm{ml}$ of phosphate buffer, $p \mathrm{H} 7.25(0.1 \mathrm{M})$. The homogenate was then transferred to glass tubes, stoppered, and frozen at $-4^{\circ} \mathrm{C}$ until time of assay.

\section{Assay Methodology}

The amount of warfarin in plasma and tissues at various time intervals was determined by the modified O'Reilly method with a few modifications (1). The additional changes involved the extraction procedure, elimination of separatory funnels, and use of pyrex glass wool for filtering purposes. The final method is given in detail below.

Blank rat plasma and tissue samples freshly frozen at $-4^{\circ} \mathrm{C}$, followed by thawing, homogenizing with warfarin as a spike, and refreezing at the end of 4 months, and finally thawing again at intervals over the next 5 months, yielded excellent Beer's law plots. O'Reilly also reported that results of warfarin determinations on plasma, urine, and stool stored in the frozen state for several months, even when the specimens were repeatedly thawed and frozen, were not significantly different from those obtained on fresh samples (2). It was also determined that human plasma, O-positive and not 
over $24 \mathrm{hr}$ old, kept frozen for 2 weeks, gave the same blank value in the assay as when fresh. However, blank values were found to increase when the same plasma that had been kept refrigerated at $4^{\circ} \mathrm{C}$ was used.

The results of calibration studies on warfarin-spiked human plasma, rat plasma, and rat tissues are presented in Table I. Human plasma, 4-ml samples, was spiked from 0.13 to $12 \mu \mathrm{g} / \mathrm{ml} ; 2-\mathrm{ml}$ samples were spiked from 0.15 to $12 \mu \mathrm{g} / \mathrm{ml}$. Rat plasma, 2-ml samples, was spiked from 0.25 to $7.5 \mu \mathrm{g} / \mathrm{ml}$; rat tissues were spiked from 2 to $30 \mu \mathrm{g} / \mathrm{g}$.

Table R. Warfarin Tissue and Plasma Assay Calibration Data: Slopes of Least-Squares Lines Forced Through the Origin for Plots of Absorbance Against Amount of Warfarin in $\mu \mathrm{g} / \mathrm{ml}$ of Final $\mathrm{NaOH}$ Solution

\begin{tabular}{clc}
\hline $\begin{array}{c}\text { Shaking } \\
\text { time }(\mathrm{min})\end{array}$ & \multicolumn{1}{c}{ Sample } & Slope $^{a}$ \\
\hline 20 & Human plasma, $4 \mathrm{ml}$ & 0.263 \\
20 & Human plasma, $4 \mathrm{ml}$ & 0.314 \\
20 & Human plasma, $4 \mathrm{ml}$ & 0.289 \\
20 & Human plasma, $4 \mathrm{ml}$ & 0.282 \\
20 & Human plasma, $4 \mathrm{ml}$ & 0.282 \\
10 & Human plasma, $4 \mathrm{ml}$ & 0.312 \\
10 & Human plasma, $4 \mathrm{ml}$ & 0.299 \\
10 & Human plasma, $4 \mathrm{ml}$ & 0.299 \\
10 & Human plasma, $4 \mathrm{ml}$ & 0.329 \\
10 & Human plasma, $4 \mathrm{ml}$ & 0.380 \\
20 & Human plasma, $2 \mathrm{ml}$ & 0.311 \\
20 & Human plasma, $2 \mathrm{ml}$ & 0.274 \\
20 & Human plasma, $2 \mathrm{ml}$ & 0.265 \\
10 & Human plasma, $2 \mathrm{ml}$ & 0.359 \\
10 & Human plasma, $2 \mathrm{ml}$ & 0.336 \\
10 & Rat plasma, $2 \mathrm{ml}$ & 0.317 \\
10 & Rat plasma, $2 \mathrm{ml}$ & 0.338 \\
20 & Rat brain homogenate, $4 \mathrm{ml}$ & 0.321 \\
20 & Rat brain homogenate, $4 \mathrm{ml}$ & 0.289 \\
20 & Rat heart homogenate, $4 \mathrm{ml}$ & 0.298 \\
20 & Rat heart homogenate, $4 \mathrm{ml}$ & 0.320 \\
20 & Rat lung homogenate, $4 \mathrm{ml}$ & 0.348 \\
20 & Rat lung homogenate, $4 \mathrm{ml}$ & 0.327 \\
20 & Rat spleen homogenate, $4 \mathrm{ml}$ & 0.303 \\
20 & Rat spleen homogenate, $4 \mathrm{ml}$ & 0.328 \\
20 & Rat liver homogenate, $4 \mathrm{ml}$ & 0.336 \\
20 & Rat liver homogenate, $4 \mathrm{ml}$ & 0.334 \\
\hline
\end{tabular}

${ }^{a}$ Average slope $=0.313$, which is absorbance units $/ \mu \mathrm{g}$ warfarin $/ \mathrm{ml}$ final $\mathrm{NaOH}(2.5 \mathrm{~N})$. (Student's $t$ test gave no significant difference between slopes of 10 -min vs. 20 -min shaking periods nor between slopes of $4 \mathrm{ml}$ plasma, $2 \mathrm{ml}$ plasma, and $4 \mathrm{ml}$ tissue homogenates.) 
The assay procedure for the determination of warfarin in rat (or human) plasma and tissue was as follows:

1. Twenty milliliters of 1,2-ethylenedichloride (EDC), analytical grade, was pipetted into $50-\mathrm{ml}$ round-bottom centrifuge tubes to receive teflon-lined screw caps for the given number of samples and blanks.

2. Samples were added as follows:

a. Human plasma: Four milliliters was layered onto EDC surface, and warfarin spike $(\mu \mathrm{l})$ was added and gently distributed into plasma without mixing layers, followed by addition of $3 \mathrm{ml} \mathrm{HCl}$ $(1 \mathrm{~N})$.

b. Rat plasma: Two milliliters was layered and spiked as above, followed by $5 \mathrm{ml} \mathrm{HCl}(0.6 \mathrm{~N})$.

c. Rat tissue: Four milliliters of a uniformly dispersed $10 \%$ tissue homogenate, using the tissue grinder if previously prepared and frozen, in phosphate buffer, $p \mathrm{H} 7.25(0.1 \mathrm{M})$, was layered as above onto EDC surface, and warfarin spike $(\mu \mathrm{l})$ was added, followed by $3 \mathrm{ml} \mathrm{HCl}(1 \mathrm{~N})$.

3. Centrifuge tubes were capped and agitated horizontally in a Kahn (Ebberback) shaker: $10 \mathrm{~min}$ for plasma extraction, $20 \mathrm{~min}$ for tissue homogenates. Too much shaking resulted in emulsification and high blank values; inadequate shaking time resulted in incomplete transfer of warfarin into the organic phase (2).

4. Tubes were then centrifuged at $500 \mathrm{~g}, 4^{\circ} \mathrm{C}$, for $4 \mathrm{~min}$; the top aqueous layer was discarded; $5 \mathrm{ml}$ of the same phosphate buffer was added to remove interfering substances extracted by the relatively polar EDC (2); tubes were capped and agitated horizontally for $10 \mathrm{~min}$ and again centrifuged as above.

5. The aqueous buffer was discarded; exactly $15 \mathrm{ml}$ of the organic layer was transferred to a new set of 50-ml round-bottom centrifuge tubes, followed by exactly $5 \mathrm{ml}$ of $\mathrm{NaOH}(2.5 \mathrm{~N})$ and horizontal agitation for $5 \mathrm{~min}$. The organic layer was reduced by $10 \mathrm{ml}$ with a pipette, and the balance including the $5-\mathrm{ml}$ aqueous layer was filtered through pyrex glass wool into $15-\mathrm{ml}$ vacutainers and centrifuged at $500 \mathrm{~g}, 8 \mathrm{~min}$, at room temperature.

6. The ultraviolet absorbance of the warfarin solution was read within $2 \mathrm{hr}$ using a Gilford model 2400 spectrophotometer and $7.5-\mathrm{cm}$ quartz cuvettes. The instrument was nulled against the blank for each sample reading taken at 360 and $308 \mathrm{~nm}$. The net absorbance was then calculated by taking the difference between meter readings at 308 and $360 \mathrm{~nm}$. (The cuvettes were cleaned in $50 \%$ nitric acid for $24 \mathrm{hr}$ following each assay series of 16 samples; absolute ethyl 
alcohol was used to thoroughly dry the sample cuvette after cleaning between each sample reading.)

7. The inherent absorbance of the two cuvettes, following the nitric acid soak, was determined by use of distilled water to be 0.005 and 0.009 . The difference between the two cuvettes was considered negligible, and therefore a correction factor was not included in the calculation of the net absorbance for each sample. The $7.5-\mathrm{cm}$ cuvettes were tagged so that one was used only for the sample, the other for the blank.

8. Warfarin concentration in samples of plasma or tissue was calculated as follows based on a $7.5-\mathrm{cm}$ pathlength:

a. Warfarin concentration in plasma $(\mu \mathrm{g} / \mathrm{ml})=($ net $A \times 5 \times 20) /$ $0.313 \times \mathrm{ml}$ of plasma $\times 15$ ).

b. Warfarin concentration in tissue $(\mu \mathrm{g} / \mathrm{g})=($ net $A \times 5 \times 20 \times 1) /$ $(0.313 \times 4 \times 15 \times 0.1)=$ net $A / 0.0188$.

\section{Estimation of Free (Unbound) Warfarin Plasma Concentrations}

The equation of Wosilait (3), shown as equation 1, was used for estimation of free (unbound) warfarin tissue concentrations. The constants are those for human serum albumin, but our values of $0.9-1.0 \%$ free, calculated with the equation, are very similar to the $0.2-1.5 \%$ free reported by Levy and Yacobi (4) for the rat:

$$
C_{B}=\frac{K_{1} n_{1} P C_{F}}{1+K_{1} C_{F}}+\frac{K_{2} n_{2} P C_{F}}{1+K_{2} C_{F}}
$$

where $C_{B}$ is the concentration of protein-bound warfarin in nmoles $/ \mathrm{ml}, C_{F}$ is the concentration of free (unbound) warfarin in nmoles/ml, $K_{1}$ and $K_{2}$ are the association constants in liters/mole, $n_{1}$ and $n_{2}$ are the binding capacities, and $P$ is the concentration of serum albumin in nmoles $/ \mathrm{ml}$. Division of the top and bottom of the right-hand sides by $K_{1}$ and $K_{2}$, respectively, and substitution of Wosilait's values of $K_{1}=0.089 \mathrm{ml} / \mathrm{nmole}$ (corresponding to $8.94 \times 10^{4} \mathrm{liters} / \mathrm{mole}$ ), $K_{2}=0.0067 \mathrm{ml} / \mathrm{nmole}$ (corresponding to $6.7 \times 10^{3}$ liters $/$ mole), $n_{1}=2, n_{2}=4$, and $P=580 \mathrm{nmole} / \mathrm{ml}$ gave

$$
C_{B}=\frac{1160 C_{F}}{11.24+C_{F}}+\frac{2320 C_{F}}{149.25+C_{F}}
$$



by

If the total plasma concentration is represented by $C_{p}$, then $C_{p}$ is given

$$
C_{p}=C_{F}+\frac{1160 C_{F}}{11.24+C_{F}}+\frac{2320 C_{F}}{149.25+C_{F}}
$$

Let

$$
y=C_{F}+\frac{1160 C_{F}}{11.24+C_{F}}+\frac{2320 C_{F}}{149.25+C_{F}}-C_{p}
$$

A Hewlett-Packard electronic calculator program was written for the latter equation to solve for $C_{F}$ iteratively from a given value of $C_{p}$. Trial values of $C_{F}$ were entered until $y \simeq 0$. The free drug concentrations calculated by this method agreed very well with those given by Wosilait in his article. The free warfarin concentrations in rat plasma observed in this study, calculated by the above method, are shown in Table II below the total warfarin concentrations. The free drug concentrations varied from $1.0 \%$ (when $C_{p}=80.1 \mu \mathrm{g} / \mathrm{ml}$ ) to $0.90 \%$ (when $C_{p}=37.6 \mu \mathrm{g} / \mathrm{ml}$ ) in our rat studies. Concentrations were interconverted using $C_{F}(\mathrm{nmoles} / \mathrm{ml})=3.24 C_{F}(\mu \mathrm{g} / \mathrm{ml})$.

\section{RESULTS}

Table II lists the observed average total plasma and tissue concentrations and the calculated free warfarin plasma concentrations.

Table III lists the ratios of the average tissue concentration to the average total plasma concentration. For each tissue, the ratio remained essentially constant from $0.0833 \mathrm{hr}(5 \mathrm{~min})$ to $4 \mathrm{hr}$ with reasonable small coefficients of variation. From the data of Anderson (5), similar ratios were calculated and these are shown in Table IV. The liver/plasma and brain/plasma ratios calculated from Anderson's data agree very well with those calculated data obtained in our study. We observed higher average lung/plasma and heart/ plasma ratios than Anderson and a lower spleen/plasma ratio than Anderson. However, Anderson's data were much more variable than the data in our study, as indicated by the coefficients of variation. Since the dose used by Anderson was only $2 \mathrm{mg} / \mathrm{kg}$, and the dose used in our studies was $10 \mathrm{mg} / \mathrm{kg}$, and similar ratios were observed in the two studies, it appeared to be unnecessary to perform additional tissue studies. The dose range of interest was $0-10 \mathrm{mg} / \mathrm{kg}$, and it appeared unlikely that there was a "dose dependency" in this range.

The diffusible form of warfarin is the free (unbound) form in plasma water, hence tissue concentrations should really be related to the free (unbound) concentrations. The ratios of tissue concentration to free warfarin 


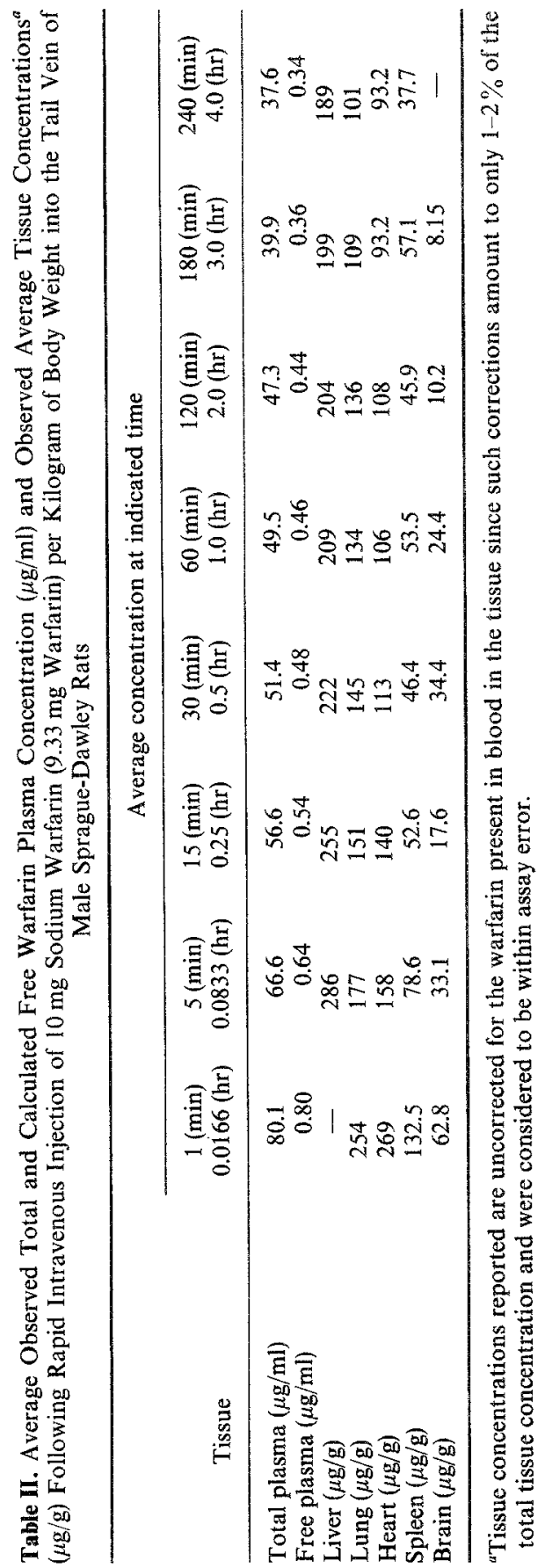




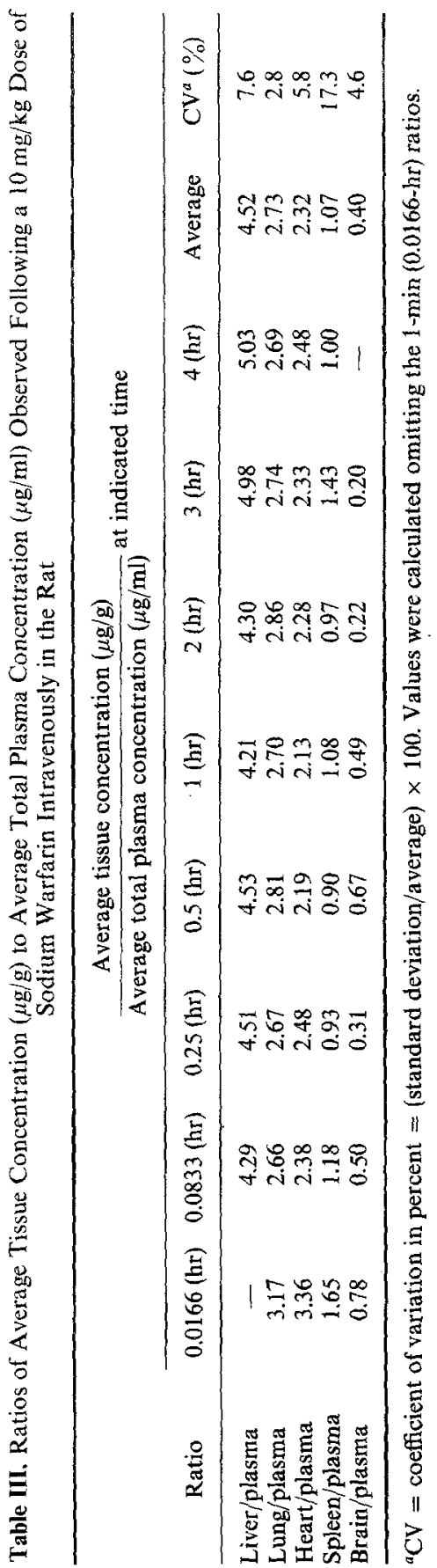




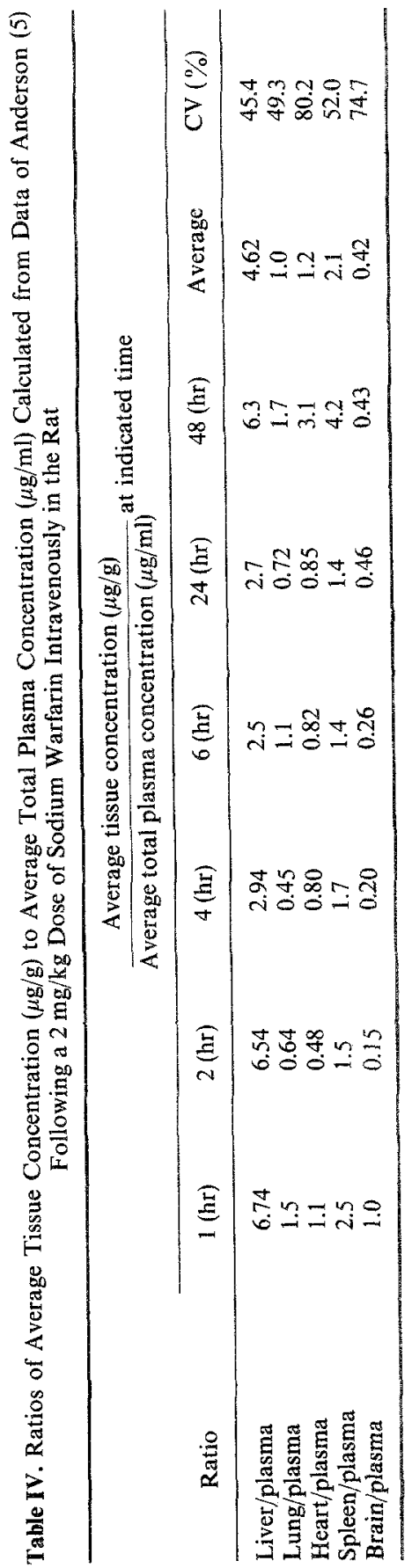


concentrations are given in Table V. For each tissue, from 0.0833 to $4 \mathrm{hr}$, the ratio remained essentially constant with reasonably small coefficients of variation. However, as indicated before, in the concentration range studied, free (unbound) warfarin ranged from only 0.90 to $1.0 \%$ of total plasma concentrations. This is well within analytical error; hence, in the case of warfarin in the rat, use of total plasma concentrations is satisfactory for the model shown in Scheme II.

\section{Fitting of Total Warfarin Plasma Concentration-Time Data}

The total plasma concentrations listed in Table II were "stripped" on semilogarithmic graph paper, using an electronic calculator to calculate the least-squares lines. The data were tentatively fitted to the equation

$$
\hat{C}_{p}=27.83 e^{-8.66 t}+54.60 e^{-0.0942 t}
$$

On the basis of these results, the classical interpretation is that the data obey the two-compartment open model with rapid intravenous injection:

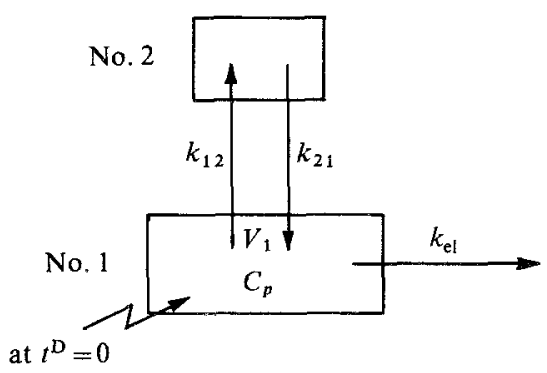

Scheme I

Equations appropriate to this model are given below:

$$
\begin{gathered}
\hat{C}_{p}=\frac{C_{p}^{0}}{(\alpha-\beta)^{-}}\left[\left(k_{21}-\beta\right) e^{-\beta t}-\left(k_{21}-\alpha\right) e^{-\alpha t}\right] \\
\alpha=\frac{1}{2}\left[\left(k_{12}+k_{21}+k_{\mathrm{el}}\right)+\sqrt{\left(k_{12}+k_{21}+k_{\mathrm{el}}\right)^{2}-4 k_{21} k_{\mathrm{el}}}\right] \\
\beta=\frac{1}{2}\left[\left(k_{12}+k_{21}+k_{\mathrm{el}}\right)-\sqrt{\left(k_{12}+k_{21}+k_{\mathrm{e} 1}\right)^{2}-4 k_{21} k_{\mathrm{el}}}\right]
\end{gathered}
$$

Equation 6 may also be written as equation 9:

$$
\widehat{C}_{p}=A e^{-\alpha t}+B e^{-\beta t}
$$




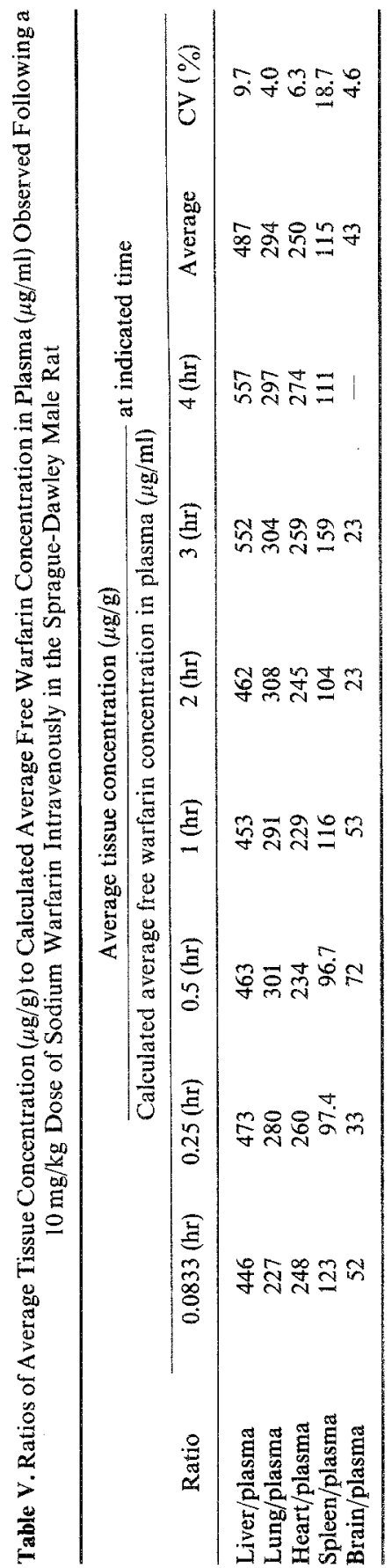


where

$$
\begin{aligned}
& A=D\left(k_{21}-\alpha\right) / V_{1}(\beta-\alpha) \\
& B=D\left(k_{21}-\beta\right) / V_{1}(\alpha-\beta)
\end{aligned}
$$

The model parameters were estimated from the equations

$$
\begin{aligned}
V_{1} & =D / C_{p}^{0}=D /(A+B) \\
k_{21} & =(A \beta+B \alpha) /(A+B) \\
k_{\mathrm{el}} & =\alpha \beta / k_{21} \\
k_{12} & =\alpha+\beta-k_{21}-k_{\mathrm{el}}
\end{aligned}
$$

Using the values $A=27.83, \alpha=8.66, B=54.60$, and $\beta=0.0942$ (by comparison of equations 5 and 9) and equations 13 through 15 , the preliminary estimates $k_{21}=5.77, k_{\mathrm{el}}=0.141$, and $k_{12}=2.85 \mathrm{hr}^{-1}$ were obtained.

The plasma concentration-time data and these preliminary estimates were then used as input data, and the data were fitted to equations 6 through 8 using the program NONLIN and the IBM 360/67 digital computer. The results of the fitting are shown in Table VI. The fit was excellent. Substitution of the estimated parameters into equation 6 gave equation 16 . Hence equation 16 is an improvement over equation 5 since the sum of squared deviations is

\begin{tabular}{|c|c|c|c|c|}
\hline \multicolumn{4}{|c|}{$\begin{array}{l}\text { Least-squares } \\
\text { estimate }\end{array}$} & Standard deviation \\
\hline \multirow[t]{5}{*}{$\begin{array}{l}k_{12}\left(\mathrm{hr}^{-1}\right) \\
k_{21}\left(\mathrm{hr}^{-1}\right) \\
k_{\mathrm{el}}\left(\mathrm{hr}^{-1}\right) \\
C_{1}^{0}(\mu \mathrm{g} / \mathrm{ml})\end{array}$} & & $\begin{array}{r}3.4 \\
6.6 \\
0.1 \\
84.7\end{array}$ & & $\begin{array}{l}0.846 \\
1.39 \\
0.0148 \\
2.68\end{array}$ \\
\hline & \multicolumn{2}{|c|}{ Derived parameter } & \multicolumn{2}{|c|}{ Parameter value } \\
\hline & $\begin{array}{l}\alpha\left(\mathrm{hr}^{-1}\right) \\
\beta\left(\mathrm{hr}^{-1}\right) \\
V_{1}(\text { liters } / \mathrm{kg}\end{array}$ & & $\begin{array}{r}10.27 \\
0.095 \\
0.110\end{array}$ & \\
\hline & \multicolumn{3}{|c|}{ Measures of fit } & Value \\
\hline & \multicolumn{2}{|c|}{$\begin{array}{l}\text { Sum of squared deviations } \\
\text { Coefficient of determination }\end{array}$} & $\begin{array}{l}\text { Coefficient of determination } \\
\text { Correlation coefficient for } \hat{C}_{p} \text { on } C_{p}\end{array}$ & $\begin{array}{l}7.74 \\
1.00 \\
0.997\end{array}$ \\
\hline
\end{tabular}
lower for equạtion 16 than for equation 5 .

$$
\hat{C}_{p}=29.97 e^{-10.27 t}+54.73 e^{-0.0953 t}
$$

Table VI. Results of Nonlinear Least-Squares Fitting of Average Total Plasma Concentration Data 


\section{Fitting of Tissue Concentration Data}

Results presented in Table III suggested the plot shown in Fig. 1. In Fig. 1, the tissue concentration is plotted against the total plasma concentration. For each tissue, the data from 5 to $240 \mathrm{~min}$ appeared to be linear. Extrapolation of the lines and forcing the lines through the origin appeared to be justified on the basis of the data in Tables III and IV. The data obtained at 1 min after injection were lower than the "line values" since mixing had probably not been completed.

The ratios of average tissue concentration to total plasma concentration given in Table III are plotted in Fig. 2. For lung, heart, spleen, and possibly brain, the ratios appear to be randomly distributed about the average ("line values") drawn in the figure. However, for liver there appear to be definite trends in the data.

On the basis of the above results, the tissue concentration data were fitted as follows.

Approach No. 1: The total plasma concentrations and the lung, heart, spleen, and brain tissue concentrations were simultaneously fitted to equations, 7,8 , and 17 through 21 using the data from 0.0833 to $4 \mathrm{hr}$, the program NONLIN, and the IBM 360/67 digital computer.

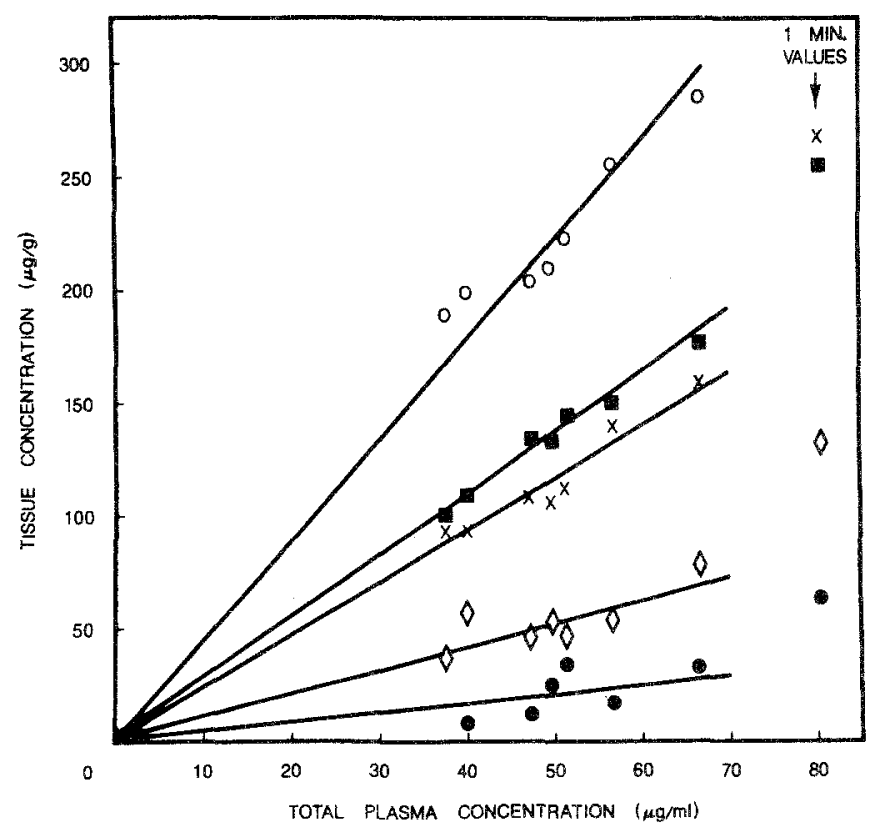

Fig. 1. Warfarin tissue concentrations relative to total plasma concentration. Symbols: $O$, liver, slope $4.44 ; 0$, lung, slope $2.73 ; \times$, heart, slope $2.33 ; \diamond$, spleen, slope $1.03 ;$, brain, slope 0.41 . 


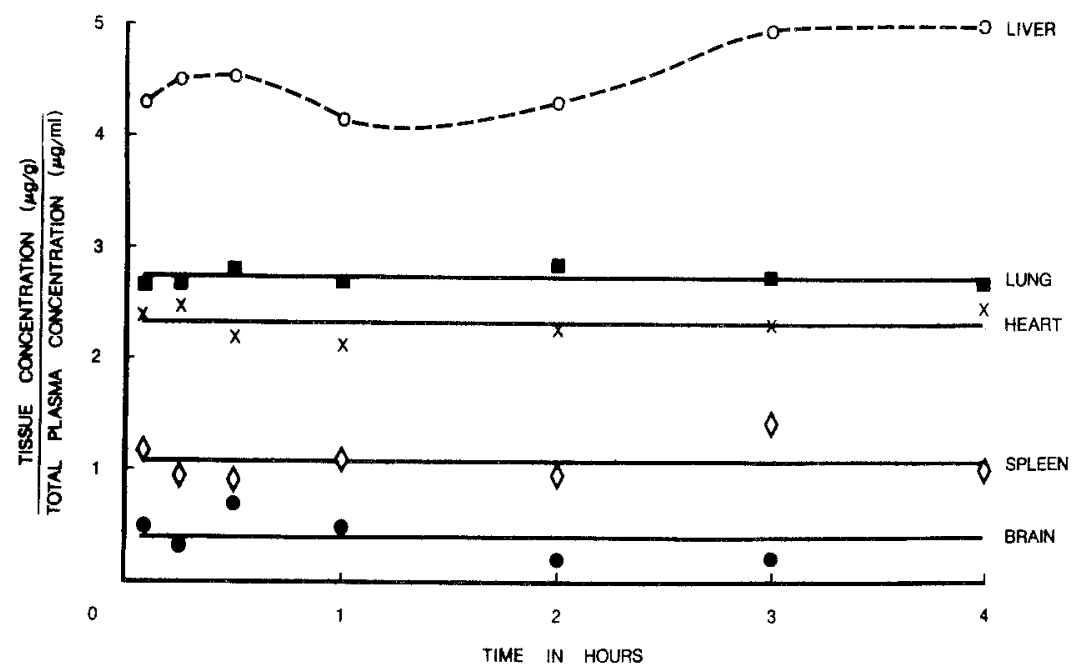

Fig. 2. Ratios of average tissue concentrations to total plasma concentration given in Table III.

$$
\begin{aligned}
\text { Plasma: } C_{p} & =\frac{C_{p}^{0}}{\alpha-\beta}\left[\left(k_{21}-\beta\right) e^{-\beta t}-\left(k_{21}-\alpha\right) e^{-\alpha t}\right] \\
\text { Lung: } T_{1} & =B_{1} \cdot C_{p} \\
\text { Heart: } T_{2} & =B_{2} \cdot C_{p} \\
\text { Spleen: } T_{3} & =B_{3} \cdot C_{p} \\
\text { Brain: } T_{4} & =B_{4} \cdot C_{p}
\end{aligned}
$$

The preliminary estimates of $B_{1}$ through $B_{4}$ were the slopes of the lines drawn in Fig. 1 . The preliminary estimates of $k_{12}, k_{21}$, and $k_{\mathrm{el}}$ used were the least-squares estimates shown in Table VI. The results of the simultaneous fitting are shown in Table VII and Fig. 3. The fits were excellent. The overall coefficient of determination was 0.995 and the overall Corr value was 0.991 . The standard deviations of the $B_{1}$ through $B_{4}$ values were very small relative to the size of the estimates. Both the univariate and s-plane $95 \%$ confidence intervals of the $B_{1}$ through $B_{4}$ values are perhaps the smallest reported to date for biological data. For example, the univariate $95 \%$ confidence interval for $B_{1}$ (lung) was 2.41-3.05 and the s-plane $95 \%$ confidence interval was $2.08-3.38$. The percent deviations of the model-predicted concentrations from the observed concentrations are shown in Table VIII. The deviations appeared to be reasonably random. Figure 3 is a Cartesian coordinate plot showing the results of the simultaneous fitting of the plasma 
Table VII. Results of Simultaneous Fitting of Tissue and Total Plasma Concentrations of Warfarin in the Rat Following Rapid Intravenous Injection of a $10 \mathrm{mg} / \mathrm{kg}$ Dose of Sodium Warfarin Equivalent to $9.33 \mathrm{mg}$ Warfarin Acid per Kilogram

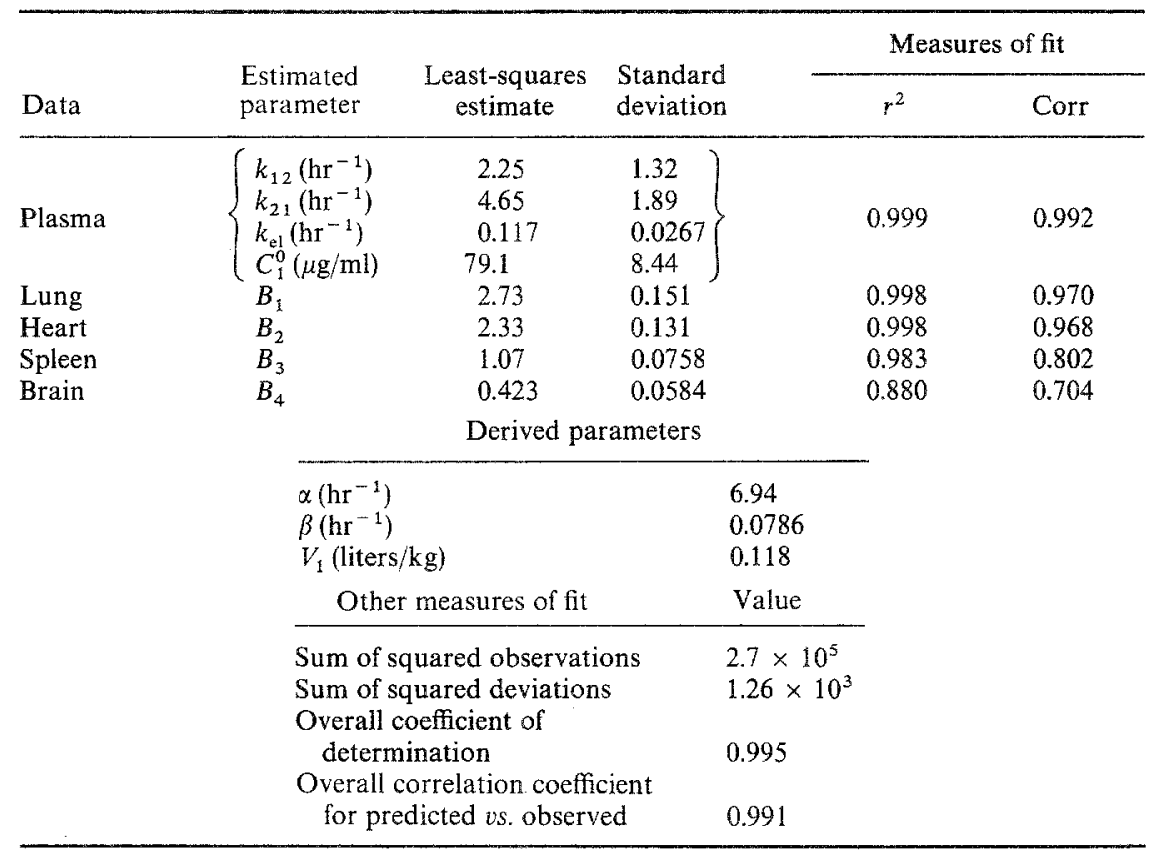

concentration data and the tissue concentrations for lung, heart, spleen, and brain. The lines drawn through the points are based on equations 17 through 21 and the least-squares estimates of the parameters shown in Table VII. The theoretical line drawn through the liver concentration data in Fig. 3 is discussed subsequently.

Approach No. 2: The tissue concentrations of lung, heart, spleen, and brain were simultaneously fitted to equations 18 through 21 and $C_{p}$ was given by equation 17 . The program NONLIN and the IBM 360/67 digital computer were used as formerly. The initial estimates used for $B_{1}$ through $B_{4}$ were the slopes of the line shown in Fig. 1 . The results of this fitting are given in Table IX. The least-squares estimates of the proportionality constants, $B_{1}$ through $B_{4}$, obtained by Approach No. 1 and Approach No. 2 are identical, as can be seen by comparing the estimates in Tables VII and IX. The simultaneous fit by Approach No. 2 was also excellent as seen by the measures of fit and low values of the standard deviations and $95 \%$ confidence intervals of the parameters shown in Table IX.

\section{Fitting of Liver Concentration Data}

Figure 2 indicates that unlike for the other tissues measured the liver concentration/plasma concentration ratio does not appear to be constant. 


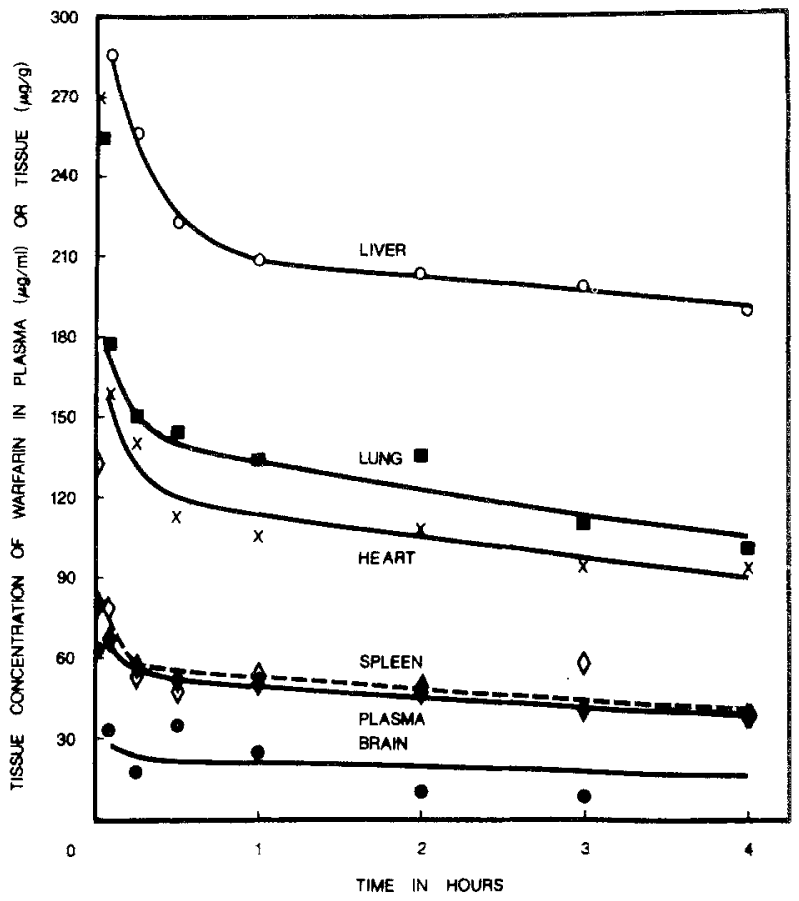

Fig. 3. Line through liver concentrations is based on equation (21): $\hat{L}=102 e^{-3.66 t}+212 e^{-0.0257 t}$. Lines through other tissue and plasma concentrations are based on simultaneous computer fitting (Table VII), resulting in the following equations: lung concentration $=2.73 C_{p}$, heart concentration $=2.33 C_{F}$, spleen concentration $=1.07 C_{p}$; brain concentration $=0.423 C_{p}$; $C_{p}=52.73 e^{-0.0786 t}+26.34 e^{-6.94 t}$, where $C_{p}$ is the total plasma concentration.

The liver concentration data were separately fitted to a double exponential equation using the program NONLIN and the IBM 360/67 digital computer. The least-squares equation obtained is given as equation 22 :

$$
\hat{L}=102 e^{-3.66 t}+212 e^{-0.0257 t}
$$

where $\hat{L}$ is the estimated liver concentration in $\mu \mathrm{g} / \mathrm{g}$ and $t$ is time in hours. The fit was excellent with $r^{2}=1.000$, Corr $=0.997, \Sigma L^{2}=3.56 \times 10^{5}$, and $\Sigma(\hat{L}-L)^{2}=40.2$. The line drawn through the liver concentration points in Fig. 3 is based on equation 12.

The $\alpha$ value of 3.66 in equation 21 is quite different from the $\alpha$ value of 10.27 obtained in fitting the total plasma concentration data (Table VI) or the $\alpha$ value of 6.94 obtained in simultaneous fitting of the plasma concentrations and tissue concentrations observed in lung, heart, spleen, and brain 
Table VIII. Percent Deviations of Model-Predicted Concentrations $\left(\hat{C}_{p}\right.$ or $\left.\hat{T}\right)$ from Observed Concentrations $\left(C_{p}\right.$ or $\left.T\right)$

\begin{tabular}{|c|c|c|c|c|c|c|c|}
\hline \multirow[b]{2}{*}{ Concentration } & \multicolumn{7}{|c|}{ Percent deviation ${ }^{a}$ at indicated time } \\
\hline & $\begin{array}{c}0.0833 \\
(\mathrm{hr})\end{array}$ & $\begin{array}{l}0.25 \\
\text { (hr) }\end{array}$ & $\begin{array}{c}0.50 \\
\text { (hr) }\end{array}$ & $\begin{array}{c}1 \\
(\mathrm{hr})\end{array}$ & $\begin{array}{c}2 \\
(\mathrm{hr})\end{array}$ & $\begin{array}{c}3 \\
(\mathrm{hr})\end{array}$ & $\begin{array}{c}4 \\
(\mathrm{hr})\end{array}$ \\
\hline Plasma & 0.85 & -0.43 & 0.24 & -1.5 & -4.7 & 4.4 & 2.4 \\
\hline Lung & 3.2 & 1.5 & -2.8 & -0.65 & -9.4 & 3.8 & 3.8 \\
\hline Heart & -1.5 & -6.4 & 6.6 & 7.6 & -2.7 & 4.1 & -3.8 \\
\hline Spleen & -9.0 & 14.1 & 18.3 & -2.9 & 4.6 & -22.3 & 8.8 \\
\hline Brain & -14.1 & 35.5 & -36.6 & -15.4 & 87.0 & 116.0 & $\ldots$ \\
\hline
\end{tabular}

${ }^{a}$ For plasma, percent deviation $=\left[\left(\hat{C}_{p}-C_{p}\right) / C_{p}\right] \times 100$. For tissue, percent deviation $=[(\hat{T}-T) / T] \times 100$.

(Table VII). Similarly the $\beta$ value (0.0257) in equation 21 is quite different from the $\beta$ value of 0.0953 obtained in fitting the total plasma concentration data (Table VI) or the $\beta$ value of 0.0786 obtained in the simultaneous fitting (Table VII). These results and mass balance considerations strongly suggest that metabolites were being measured in liver as well as unchanged drug.

\section{DISCUSSION}

The data and the analyses suggest that the model for warfarin in the rat may be written as in Scheme II:

The reversible arrows between liver and plasma, lung and plasma, etc., suggest that equilibration has been achieved within a few minutes after injection into the plasma and that individual tissue levels and plasma levels within the dashed line are always directly proportional (i.e., binding is linear). The lack of direct proportionality between observed liver concentrations and plasma concentrations is attributed to measurement of metabolites along with unchanged drug when the liver tissue was analyzed, but it is assumed that proportionality would have existed if only unchanged drug had been measured directly. The portion enclosed by the dashed line in Scheme II is conceived of as "compartment No. 1" of the two-compartment open model. There may also be tissues other than those measured in this compartment. The compartment represented as the solid line circle at the top of the scheme is conceived of as "compartment No. 2" of the twocompartment open model. The first-order rate constants, $k_{12}$ and $k_{21}$, are distribution rate constants for free (unbound) warfarin in plasma water and other body fluids. The "other fluids" are most likely what is termed "interstitial lymph," which averages $12 \%$ of body weight and $20 \%$ of body water (6). Other tissues are probably part of compartment 2, also. 
Table IX. Results of Simultaneous Fitting of Tissue Concentrations of Warfarin in the Lung, Heart, Spleen, and Brain of the Rat Following Rapid Intravenous Injection of a $10 \mathrm{mg} / \mathrm{kg}$ Dose of Sodium Warfarin Equivalent to $9.33 \mathrm{mg}$ Warfarin Acid per Kilogram ${ }^{a}$

\begin{tabular}{|c|c|c|c|c|c|c|c|}
\hline \multirow[b]{3}{*}{ Tissue } & \multicolumn{5}{|c|}{ Proportionality constant $\left(B_{i}\right)$} & & \\
\hline & \multirow[b]{2}{*}{ Parameter } & \multirow{2}{*}{$\begin{array}{l}\text { Least- } \\
\text { squares } \\
\text { estimate }\end{array}$} & \multirow{2}{*}{$\begin{array}{l}\text { Standard } \\
\text { deviation }\end{array}$} & \multicolumn{2}{|c|}{$95 \%$ confidence intervals } & \multicolumn{2}{|c|}{ Measures of fit } \\
\hline & & & & Univariate & $s$-Plane & $r^{2}$ & Corr \\
\hline Lung & $B_{1}$ & 2.73 & 0.0564 & $2.61-2.84$ & $2.54-2.92$ & 0.999 & 0.978 \\
\hline Heart & $B_{2}$ & 2.33 & 0.0564 & $2.21-2.44$ & $2.14-2.52$ & 0.996 & 0.949 \\
\hline Spleen & $B_{3}$ & 1.07 & 0.0564 & $0.949-1.18$ & $0.876-1.25$ & 0.982 & 0.793 \\
\hline \multirow[t]{2}{*}{ Brain } & $B_{4}$ & 0.424 & 0.0587 & $0.302-0.545$ & $0.227-0.621$ & 0.885 & 0.747 \\
\hline & & & & & Overall & 0.995 & 0.990 \\
\hline
\end{tabular}

${ }^{a} \Sigma \mathrm{obs}^{2}=2.55 \times 10^{5} ; \Sigma \mathrm{dev}^{2}=1.31 \times 10^{3}$.

Wosilait (3) stated: "Extensive binding of a drug by serum albumin is thought to reduce both the rate of distribution of the drug and its elimination from the body" and cited B. B. Brodie as a reference. Warfarin was $99.0-99.1 \%$ bound to plasma albumin of the rat in these studies, but it was shown that within $1 \mathrm{~min}$ after intravenous injection the major fraction of the dose was bound to tissues. From 5 to $240 \mathrm{~min}$ following injection, it was shown that the major fraction of the dose could be accounted for in just five tissues.

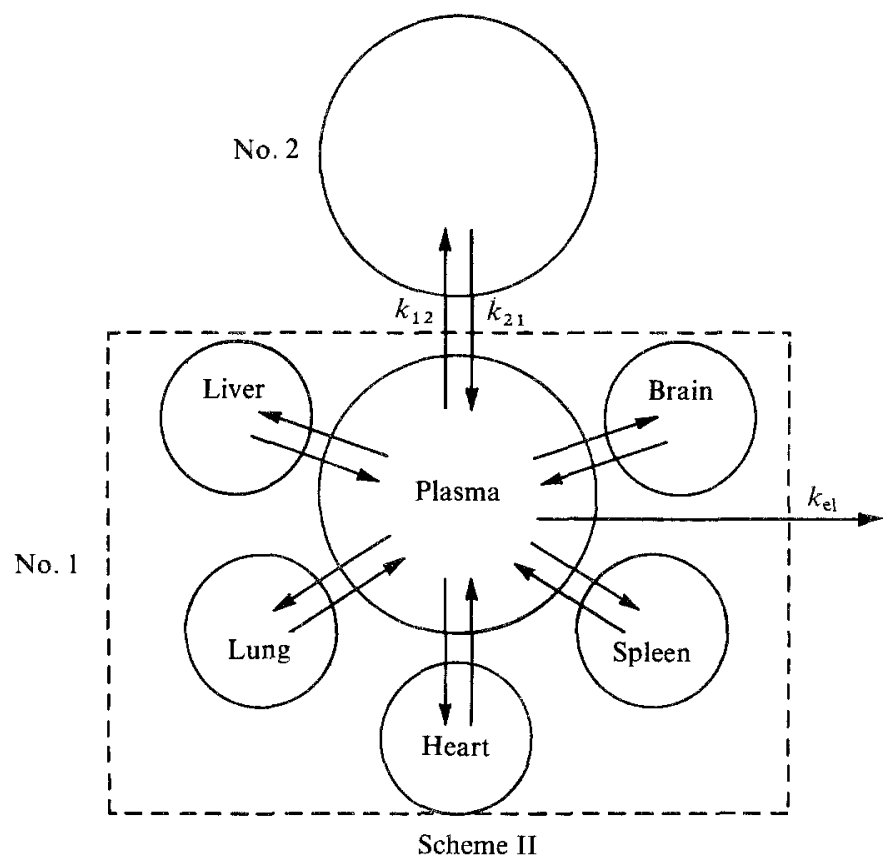


It may be assumed that the drug which is tissue bound is at least as unavailable for elimination as is the drug which is bound to albumin. Hence these data strongly suggest that binding of warfarin to serum albumin does not reduce the rate of distribution to any appreciable degree.

Wosilait (3) stated: "The warfarin in the [rat] plasma was not metabolized to any great extent." This supports the assumption made that the warfarin measured in plasma in this study was unchanged warfarin. The assay used was the same as that used by Welling et al. (1), who showed that it gave the same results as obtained by a thin-layer chromatographic assay, when 93 human plasma samples containing warfarin were assayed by both methods. Yacobi et al. (7) have recently shown the same for the rat.

It should be noted that the treatment employed, in which tissue concentrations have been related to total plasma concentrations, was feasible only with warfarin since the fraction free in plasma (from 0.009 to 0.01 in the range of plasma concentrations studied) was essentially constant. If free drug concentrations had been used, the $B_{1}$ through $B_{4}$ values in Tables VII and IX would have been about 100 times greater.

It should also be noted that for the model shown as Scheme II it is implicitly assumed that the diastereoisomers are bound to tissues and plasma proteins and metabolized at the same rates.

Commonly it is assumed that compartment No. 1 of the two-compartment model is the "plasma compartment" and compartment No. 2 is the "tissue compartment." The results of this study strongly suggest that such a description is inadequate. In the case of warfarin in the rat, it may well be that the biphasic nature of the plasma concentration curve is principally caused by distribution of warfarin between "fluid" compartments.

\section{REFERENCES}

1. P. G. Welling, K. P. Lee, U. Khanna, and J. G. Wagner. Comparison of plasma concentrations of warfarin measured by both simple extraction and TLC methods. J. Pharm. Sci. 59:1621-1625 (1970).

2. R. A. O'Reilly, P. M. Aggeler, M. S. Hoag, and L. Long. Studies on the coumarin anticoagulant drugs: The assay of warfarin and its biologic application. Thromb. Diath. Haemorrh. 8: 82-95 (1962).

3. W. D. Wosilait. The relationship between the dose of warfarin, free drug in plasma, and its elimination in the bile of rats. Res. Commun. Chem. Pathol. Pharmacol. 6:943-950 (1973).

4. G. Levy and A. Yacobi. Effect of plasma protein binding on elimination of warfarin. $J$. Pharm. Sci. 63:805-806 (1974).

5. G. F. Anderson. The distribution of warfarin (coumadin) in the rat. Thromb. Diath. Haemorrh. 18:754 757 (1967).

6. J. G. Wagner. Biopharmaceutics and Relevant Pharmacokinetics, 1 st ed., Drug Intelligence Publications, Hamilton, Ill., 1971, p. 261.

7. A. Yacobi, L. B. Wingard, and G. Levy. Comparative pharmacokinetics of coumarin anticoagulants. X. Relationship between distribution, elimination, and anticoagulant action of warfarin. J. Pharm. Sci. 63:868-872 (1974). 